\title{
Air-hydrate crystals in deep ice-core samples from Vostok Station, Antarctica
}

\author{
T. UCHIDA, \\ Department of Applied Physics, Faculty of Engineering, Hokkaido University, Sapporo 060, Japan \\ T. HONDOH, \\ Institute of Low Temperature Science, Hokkaido University, Sapporo 060, Japan \\ S. MAE, \\ Department of Applied Physics, Faculty of Engineering, Hokkaido University, Sapporo 060, Japan \\ V.YA. LIPENKOV, \\ The Arctic and Antarctic Research Institute, 199226 St Petersburg, Russia \\ P. DUVAL \\ Laboratoire de Glaciologie et Géophysique de l'Environnement, C.N.R.S., 38402 Saint-Martin-d'Hères Cedex, France
}

\begin{abstract}
Microscopic observation of air-hydrate crystals was carried out using 34 deep ice-core samples retrieved at Vostok Station, Antarctica. Samples were obtained from depths between 1050 and $2542 \mathrm{~m}$, which correspond to Wisconsin/ Sangamon/Illinoian ice. It was found that the volume and number of air-hydrate varied with the climatic changes. The volume concentration of air-hydrate in the interglacial ice was about $30 \%$ larger than that in the glacial ice. In the interglacial ice, the number concentration of air-hydrate was about a half and the mean volume of air-hydrate was nearly three times larger than that in the glacial-age ice. The air-hydrate crystals were found to grow in the ice sheet, about $6.7 \times 10^{-12} \mathrm{~cm}^{3} \mathrm{year}^{-1}$, in compensation for the disappearance of smaller ones. The volume concentration of air-hydrate was related to the total gas content by a geometrical equation with a proportional parameter $\alpha$. The mean value of $\alpha$ below $1250 \mathrm{~m}$, where no air bubbles were found, was about 0.79 . This coincided with an experimentally determined value of the crystalline site occupancy of the air-hydrate in a $1500 \mathrm{~m}$ core obtained at Dye 3 , Greenland (Hondoh and others, 1990). In the depth profile of calculated $\alpha$ for many samples, $\alpha$ in the interglacial ice was about $30 \%$ smaller than that in the glacial-age ice.
\end{abstract}

\section{INTRODUCTION}

Many air bubbles are formed in polar ice sheets when the firn changes into ice. Their size decreases as the depth of ice increases because of the overburden pressure. Subsequently, all air bubbles disappear at a certain depth. Miller (1969) suggested that air formed the clathrate hydrate in ice under a high pressure and proposed the temperature and pressure dependence of the formation and dissociation of air-hydrate.

Shoji and Langway (1982) first found air-hydrate inclusions in the Dye 3 ice core, Greenland, using an optical microscope examination conducted in their field trench laboratory. Later they revealed that a significant number of air-hydrate inclusions still existed in the deep ice-core samples obtained at Camp Century, Greenland, which were recovered in 1966, and at Byrd Station, Antarctica, in 1968 (Shoji and Langway, 1987). The shallowest depths at which they found air-hydrate inclusions in the ice cores at Dye 3, Camp Century and Byrd Station were 1092, 1099 and $727 \mathrm{~m}$, respectively. Xray diffraction studies on the natural air-hydrate in the $1500 \mathrm{~m}$ Dye 3 ice cores (Hondoh and others, 1990) revealed that it was a single crystal, and Raman spectral analysis (Nakahara and others, 1988) identified that it included $\mathrm{O}_{2}$ and $\mathrm{N}_{2}$ molecules as the guest molecules. Airhydrate crystals in deep ice cores are, therefore, storage of ancient atmospheric gases.

The ice cores studied here were obtained from deep drilling by the Soviet Antarctic Expedition at Vostok Station $\left(78^{\circ} 28^{\prime} \mathrm{S}, 106^{\circ} 48^{\prime} \mathrm{E}\right.$, altitude $\left.3488 \mathrm{~m}\right)$, East Antarctica. The mean annual temperature is $-55.5^{\circ} \mathrm{C}$ and the present snow-accumulation rate is about $2.2 \mathrm{~g}$ $\mathrm{cm}^{-2}$ year $^{-1}$. The deepest borehole reached a depth of $2546 \mathrm{~m}$ and the thickness of the ice sheet is about $3700 \mathrm{~m}$ (Jouzel and others, 1990). 
The contents of ${ }^{18} \mathrm{O}$ and deuterium (Lorius and others, 1985; Jouzel and others, 1990) revealed that the Vostok ice core included Holocene, Wisconsin, Sangamon and Illinoian ice which were designated by stages $\mathrm{A}-\mathrm{H}$. Stage A corresponds to the Holocene period. Stages B-F cover the last glacial (Wisconsin). Stage $G$ includes the peak of the last interglacial (Sangamon) and stage $\mathrm{H}$ is part of the previous glacial (Illinoian). The observations of air bubbles in Vostok ice cores (Barkov and Lipenkov, 1984; Lipenkov, 1989) were carried out in the field trench laboratory at Vostok Station soon after the ice cores were retrieved from the borehole. The results showed that the number of air bubbles in a unit volume of Holocene ice was about three times smaller than that in ice formed during the Last Glacial Maximum (LGM), while the bubble diameter was larger in Holocene than in LGM ice (Barkov and Lipenkov, 1984). It was also inferred from these observations that air-hydrates in the Vostok cores were formed at a depth of about $500 \mathrm{~m}$, and the transformation from air bubbles to air-hydrates had been completed at about $1250 \mathrm{~m}$, where all air bubbles disappeared. Deeper than this transition interval, called the transition zone, all ancient atmospheric gases older than the early Wisconsin glacial age are considered to be stored in air-hydrate crystals. The depth profiles of both the number and volume of air-hydrate are, therefore, expected to change with climatic change.

Hondoh (1989) proposed that the depth profile of the air-hydrate morphology showed annealing effects on airhydrate crystals in the ice sheet. The observation of airhydrate crystals in Dye 3 cores showed that most of the crystals had facets in the depth range where the airhydrate crystals grew actively. On the other hand, spherical crystals became dominant where the crystals stopped growing. Therefore, the depth profile of each crystal shape will indicate whether the crystals grow actively in the ice sheet or not.

In order to obtain depth profiles of the number, volume and shape of air-hydrate crystals in the ice sheet, observation of each crystal was carried out under a microscope. Vostok ice cores from deeper than the depth of air-bubble disppearance were mainly used for observation to eliminate the effects of air bubbles. The depth profiles of the number, volume and shape of the airhydrate crystals were then compared with the palaeoclimatic conditions and with total gas content.

\section{OBSERVATIONS AND RESULTS}

\section{Specimen and sample preparation}

Thirty-four Vostok ice cores were used for these observations; they were classified into two series, called "A series" and "B series", according to the storage conditions of the cores. The storage conditions of each specimen are listed in Table 1. Five specimens of A series ice core were retrieved at Vostok Station during 1980 and 1982, and stored for 6 years in France (storage temperature was about $-20^{\circ} \mathrm{C}$ ). The depths of the specimens are: $1222,1514,1796,1838$ and $2004 \mathrm{~m}$. The 1222 and $1514 \mathrm{~m}$ ice cores contained small cracks near the surface of each core. In the 1796 and $2004 \mathrm{~m}$ ice cores, no cracks were observed. The $1838 \mathrm{~m}$ ice core contained a large but thin crack extending along the central axis of the core and a small crack perpendicular to it. Since the number and size of the observed cracks were very small, it was reasonable to consider that stress relaxation after drilling had been homogeneous in each ice core. Twenty-nine specimens of B series ice core were retrieved during 1987 and 1991, and stored in the field trench (at about $-55^{\circ} \mathrm{C}$ ). The depths of the specimens are: 1005, 1150,1251, 1350,1421, 1430, $1470,1501,1651,1800,1811,1821,1851,1891,1910$, 1941, 1950, 1980, 2001, 2011, 2031, 2041, 2101, 2131, $2151,2170,2351,2452$ and $2542 \mathrm{~m}$. All of the specimens were retrieved from depths below the disappearance of bubbles, except for four specimens, i.e. $1222 \mathrm{~m}$ of A series, and 1050,1150 and $1251 \mathrm{~m}$ of $B$ series. These four specimens included a few bubbles but their number concentrations were less than $50 \mathrm{~cm}^{-3}$ (Lipenkov, 1989).

According to the stable-isotope profiles of the ice cores (Lorius and others, 1985; Jouzel and others, 1990), specimens between 1600 and $1910 \mathrm{~m}$ (stage G) are ice from the warm period, whose ages are between about 120 and 140 kyear BP (Sangamon interglacial age). The specimens of both above $1600 \mathrm{~m}$ (stages D, E and F) and below $1910 \mathrm{~m}$ (stage $\mathrm{H}$ ) are ice from cold periods (Wisconsin and Illinoian glacial age, respectively).

Thin-section samples were cut roughly from the ice cores by a band-saw to a thickness of about $5 \mathrm{~mm}$. The upper surface of the sample was polished chemically using ethyl alcohol to make it a flat plane. This polishing diminished the light scattering and gave a clear image for observation under an optical microscope. Silicone oil was

Table 1. Profiles of Vostok ice cores examined in the present study and their storage conditions

Samples Drilling year

Storage conditions

Ice-core conditions

Temperature Period Place

$\begin{array}{lllll}\text { A series } & 1980-82 & -20^{\circ} \mathrm{C} & 6-8 \text { year } & \text { France } \\ \text { B series } & 1987-91 & -55^{\circ} \mathrm{C} & 0-4 \text { year } & \text { Vostok }\end{array}$

Small cracks, bubbles No cracks, no bubbles (a few small bubbles in 1050 and $1150 \mathrm{~m}$ cores) 
applied to that surface to prevent the sample from sublimating. Supercooled water drops were applied around the sample edges to secure it to the glass plate. At that time, silicone oil was also applied between the sample and the glass plate. This freeze-on method minimized thermal distortion and eliminated the problem of light scattering by air bubbles between the sample and the glass plate.

The specimens were stored in a cold room at about $-50^{\circ} \mathrm{C}$ and all these experiments were carried out in the cold room at $-20^{\circ} \mathrm{C}$.

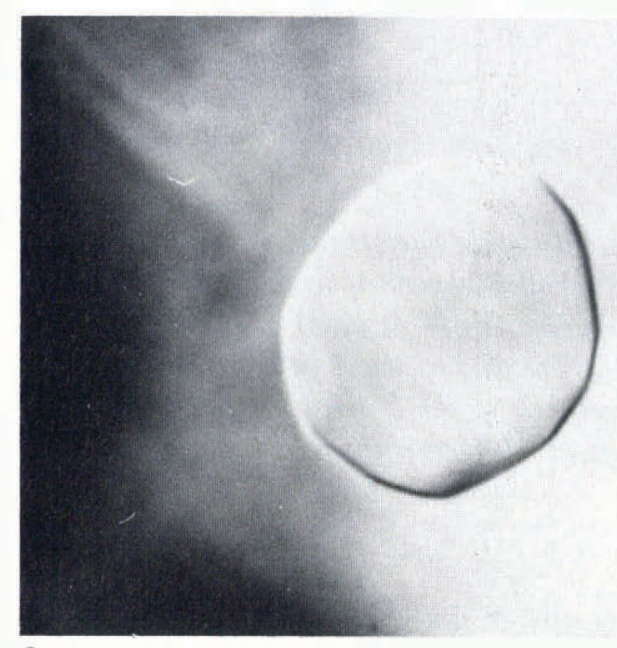

a

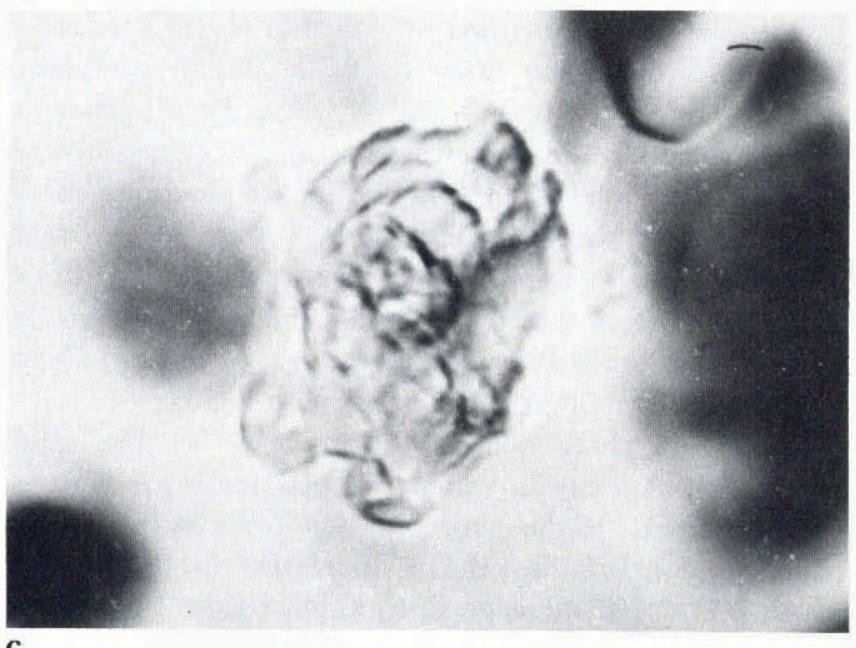

c

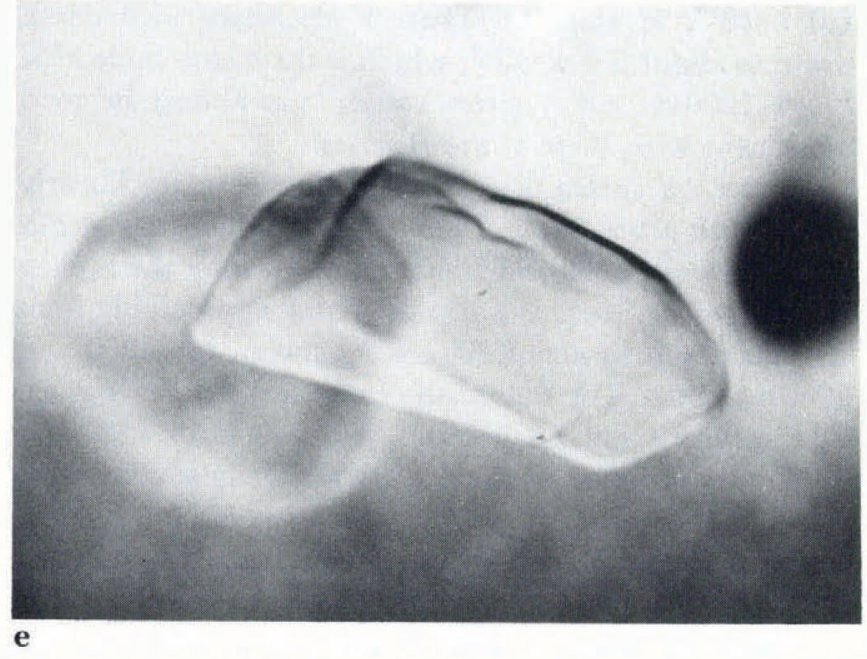

\section{Experimental methods}

The shape and diameter of each air-hydrate crystal in the sample were measured under a microscope. Air-hydrate crystals were identified using the Becke test which had been adopted by Shoji and Langway (1982).

Various shapes of air-hydrate crystals were observed in all samples. Their typical shapes are shown in Figure 1: spherical type (Fig. 1a), oval (Fig. 1b), irregular (Fig. lc), rod-like crystal (Fig. 1d), mainly rounded but partially faceted crystal (Fig. le) and polyhedral type

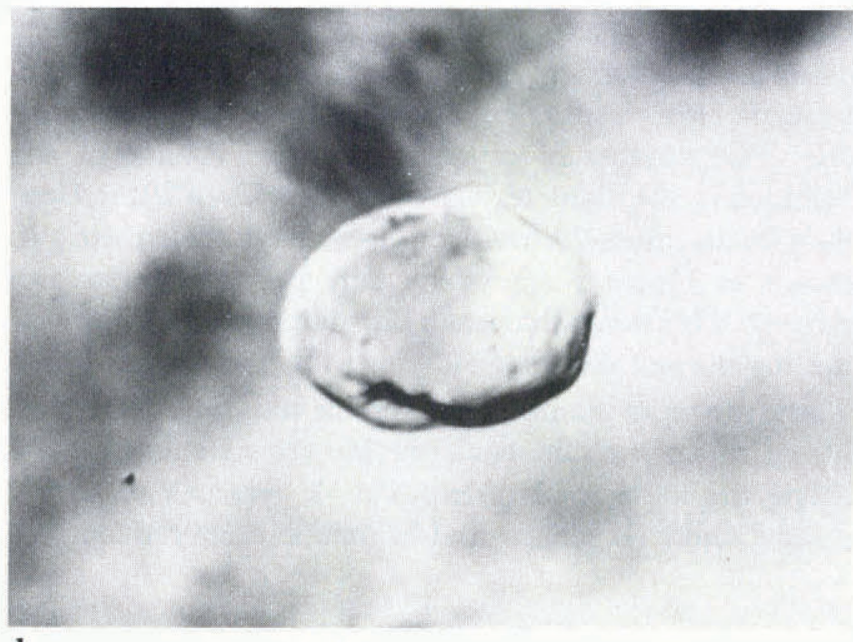

b
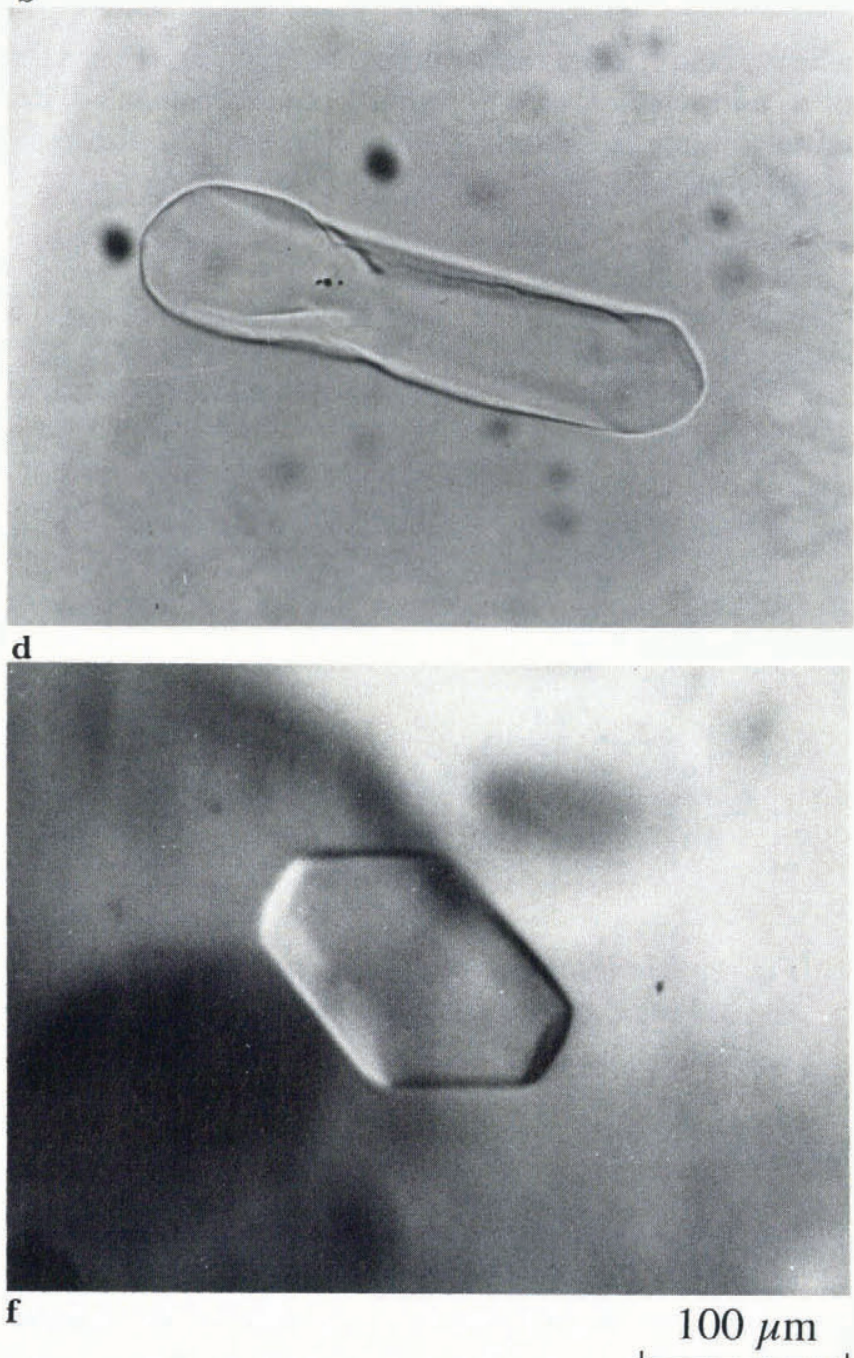

Fig. 1. Air-hydrate crystals observed in ice cores from Vostok: (a) spherical; (b) oval; (c) irregular; (d) rod-like; (e) crystals which had facets; $(f)$ polyhedral. The bar is $100 \mu \mathrm{m}$ long. 
with sharp edges (Fig. 1f). The crystal shapes are almost similar to those observed in a fresh Dye 3 ice core (Shoji and Langway, 1982). For the convenience of morphological classification and number concentration in unit volume of ice, the following three types were counted in each sample: spherical type, $N s$ (Fig. 1a and b), irregular type, $N i$ (Fig. lc and d) and faceted type, $N f$ (Fig. le and f). Then the depth profiles of the number ratio for each of these three types of air-hydrate were obtained.

In order to calculate the total volume of air-hydrate in a unit volume of the sample (volume concentration, $V$ ), the diameter distribution was also obtained for each sample. The diameter of the crystal was expressed by the diameter of the sphere of the equivalent volume obtained by using either a spherical approximation or a cylindrical one. The number of crystals in a unit volume of ice included in the diameter range at intervals of $20 \mu \mathrm{m}$ (less than $20 \mu \mathrm{m}$, from 20 to $40 \mu \mathrm{m}$, from 40 to $60 \mu \mathrm{m}$, etc.) is shown in Figure 2 (in which only six data points are shown). This shows that each distribution is well-fitted to the log-normal distribution shown by the broken lines. Then, the mean diameter $(d)$ and the standard deviations (s) of the crystals in each sample are calculated from fitting the log-normal distribution. $V$ was calculated by using $d$ and $s$ (Lipenkov and Salamatin, 1989) as follows:

$$
V=\frac{\pi}{6} N\left[d+\frac{s^{2}}{d}\right]^{3}
$$

where $N \mathrm{~cm}^{-3}$ is the total number of air-hydrate crystals in a unit volume of ice (number concentration). The mean volume of crystals $\left(V m=V / N \mathrm{~cm}^{3}\right)$ was calculated for each sample.

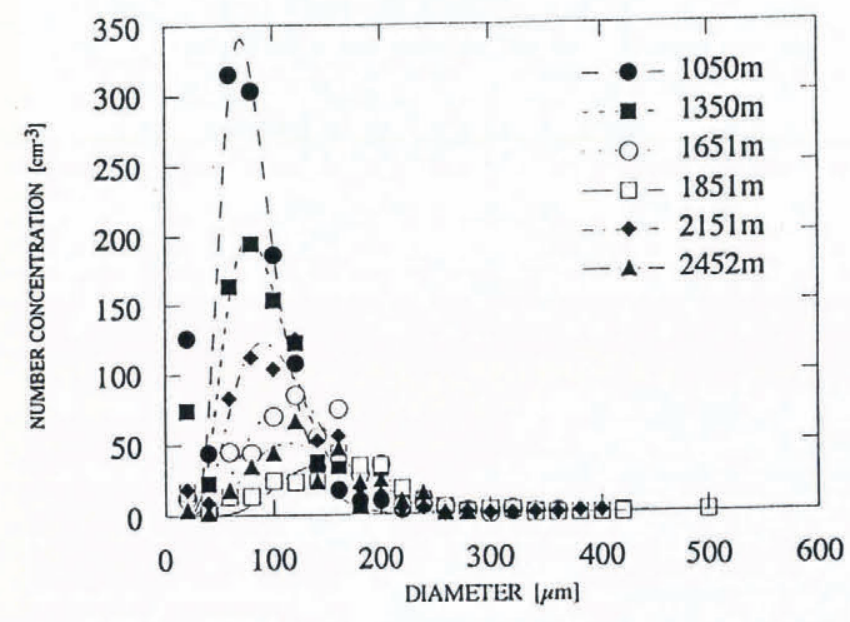

Fig. 2. Distribution of diameter of air-hydrate crystals included in six deep ice cores from Vostok.

\section{Results}

Figure 3 represents the depth profiles of the number ratio of spherical air-hydrate, $N s / N$ (circle), that of the irregular one, $N i / N$ (square), and that of the faceted one, $N f / N$ (triangle). The data of the A series are shown by solid symbols and those of the B series by open symbols. The figure shows that the main type of crystal

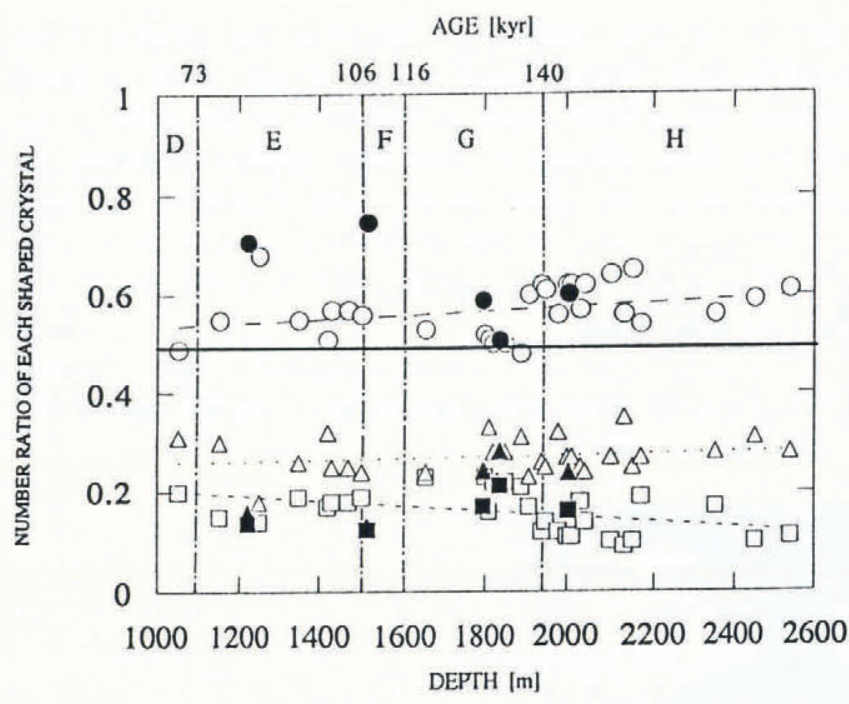

Fig. 3. Depth profiles of the number ratio of three types of air-hydrates in the Vostok ice core: spherical crystal, $\mathcal{N} s / \mathcal{N}$ (circle); irregular one, $\mathcal{N i} / \mathcal{N}$ (square) and faceted one, $\mathcal{N} f \mid \mathcal{N}$ (triangle). The data of the $A$ series are shown by solid symbols and those of the $B$ series by open symbols. The climatic stages $\mathrm{D}-\mathrm{H}$ are from Lorius and others (1985).

shape is spherical (more than 0.5 ) over all this depth region. The broken line for each number ratio obtained by the least-squares method reveals that $N s / N$ gradually increases from about 0.55 to $0.60, N i / N$ gradually decreases from 0.20 to 0.15 and $N f / N$ is almost constant at about 0.25 . In the deepest region, spherical crystals are dominant. However, $N f / N$ does not decrease with depth. It is, therefore, considered that air-hydrate crystals grow slowly in the ice sheet of this region. The figure also shows that the A series data almost coincide with those of the B series, except for $N s / N$ and $N f / N$ in the samples from 1222 and $1514 \mathrm{~m}$.

Figure 4a shows the depth profile of $V$. The solid circles show A series data and the open circles are B series data. The ends of the error bars for $V$ are estimated by using $d$ and $s$. It is clear that $V$ increases with depth from about $3.7 \times 10^{-4}$ at stage $D$ to about $6.0 \times 10^{-4}$ at the beginning of stage $\mathrm{F}$ and that it becomes constant, about $8.0 \times 10^{-4}$, at stage G. Then $V$ decreases with depth down to about $5.9 \times 10^{-4}$, which is the mean value of $V$ below $2000 \mathrm{~m}$. All A series values are almost in good agreement with those of the B series.

Figure 4b shows that $N$ generally decreases linearly with depth from about 1200 to $400 \mathrm{~cm}^{-3}$ in the depth range between 1000 and $2600 \mathrm{~m}$, as shown by the broken line. However, there is a dip deviating appreciably from the line down to about $300 \mathrm{~cm}^{-3}$ between the 1800 and $1900 \mathrm{~m}$ depths. The ends of the error bars for $N$ are given by the experimental deviations. The values for 1222 and $1514 \mathrm{~m}$ (A series, solid circles) are relatively smaller than those for 1251 and $1501 \mathrm{~m}$ (B series, open circles) but the other three samples of A series coincide well with values of the B series.

Figure 4c shows a general trend of increase in $\mathrm{Vm}$ with depth from about $0.31 \times 10^{-6}$ to about $1.1 \times$ $10^{-6} \mathrm{~cm}^{3}$ as shown by the broken line. However, there is a considerable upper deviation from the curve (about 


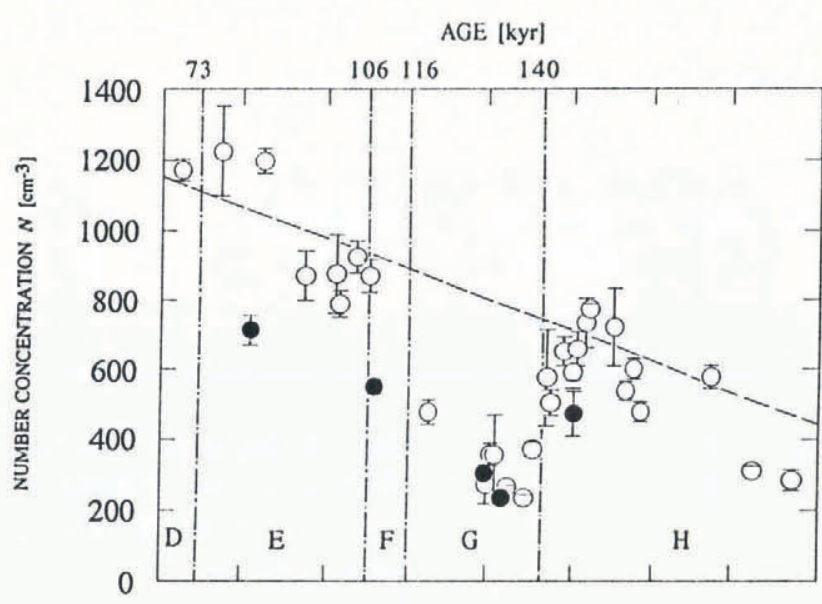

a

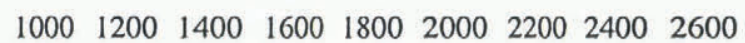

DEPrH $[\mathrm{m}]$

AGE [kyr]

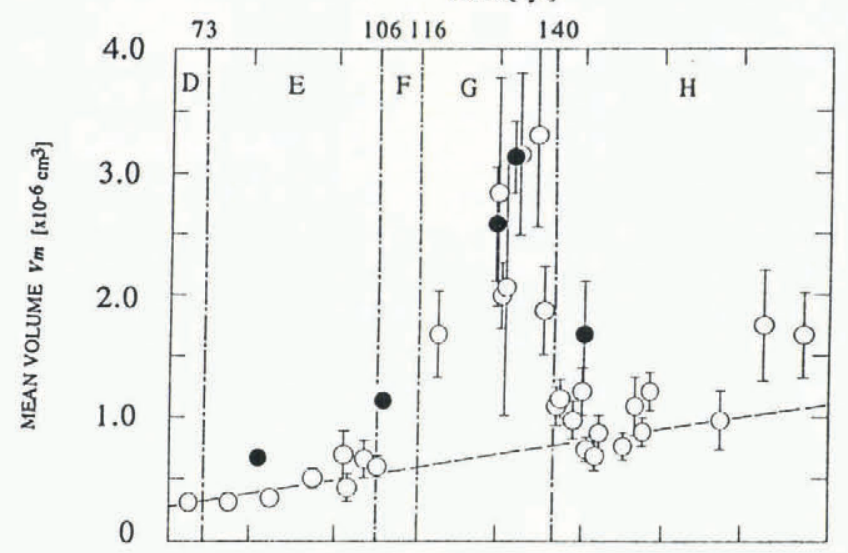

b

$\begin{array}{llllllll}1000 & 1200 & 1400 \quad 1600 \quad 1800 & 2000 & 2200 & 2400 & 2600\end{array}$ DEPTH $[\mathrm{m}]$

AGE $|k y r|$

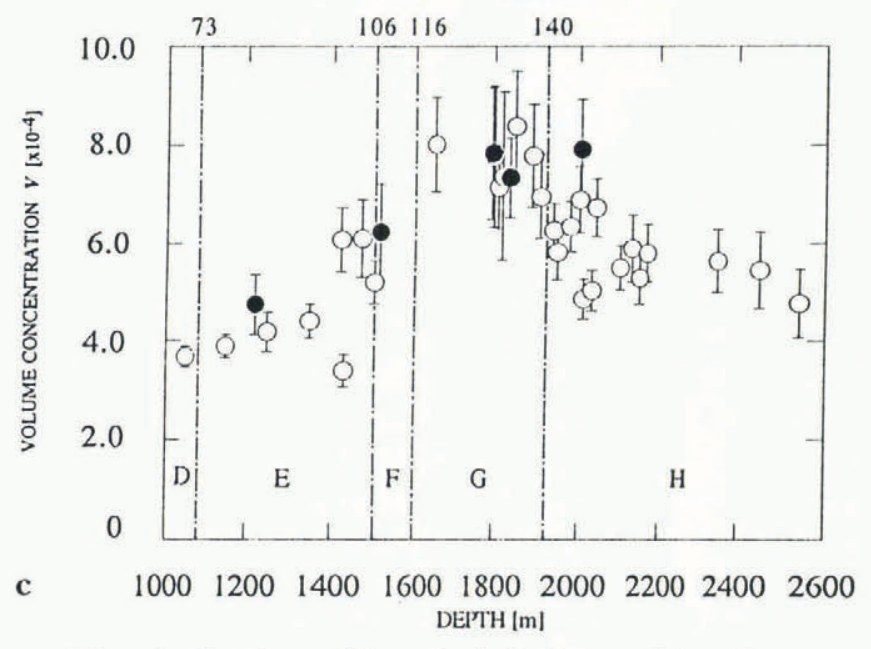

Fig. 4. Depth profiles of air-hydrate: (a) volume concentration $(V),(b)$ number concentration $(N),(c)$ mean volume $(V m)$ of the air-hydrate crystals. The error range of the measurement for $V$ and $V m$, and the experimental dispersion for $N$, are shown at each point. The data of the $A$ series are shown by solid symbols, and those of the $B$ series by open symbols.

$2.0 \times 10^{-6} \mathrm{~cm}^{3}$ ) at about $1800 \mathrm{~m}$ depth. In this case, all A series values (solid circles) coincide well with the trend of the B series (open circles).

These figures indicate considerable deviations both in $N$ and $V m$ at stage G. According to the stable-isotopic profiles (Lorius and others, 1985; Jouzel and others, 1990), the ice in this depth range is interglacial ice. It is therefore concluded that, in the Sangamon interglacial ice, air-hydrate crystals are nearly three times larger than those in stage $\mathrm{H}$, while the number concentration $N$ of air-hydrate crystals in the interglacial is about half that in stage $\mathrm{H}$. Incidentally, volume concentration $V$ of airhydrate crystals in stage $\mathrm{G}$ ice is about $30 \%$ larger than that in stage $\mathrm{H}$ ice, as can be seen in Figure $4 \mathrm{a}$.

A comparison of values for $V, N$ and $V m$ between the $A$ and $B$ series indicates that they coincide well with each other, except for the number ratio of each crystal shape and $N$ in shallower depth. This indicates that the storage conditions of the A series samples were relevant to preventing the dissociation of air-hydrate crystals, and that the ice-core storage has no influence on the depth profiles of air-hydrate below $1514 \mathrm{~m}$. The discrepancies of $N s / N, N f / N$ and $N$ between depths of 1222 and $1514 \mathrm{~m}$ (in A series) and depths of 1251 and $1501 \mathrm{~m}$ (in $B$ series) suggested that the ice-core storage may influence air-hydrate crystals in the shallower cores.

\section{DISCUSSION}

\section{Variations of $V m$ and $N$ with depth}

The broken line in Figure 4c shows that the mean volume of the air-hydrate crystals in glacial-age ice increases with depth. The results show that air-hydrate crystals grow in ice below the depth of air-bubble disappearance. Using data from ice-core chronology (Jouzel and others, 1990), we can estimate the average growth rate of air-hydrate crystals over the glacial age as follows:

$$
\frac{\mathrm{d} V m}{\mathrm{~d} t}=6.7 \times 10^{-12} \mathrm{~cm}^{3} \text { year }^{-1} .
$$

The broken line in Figure 4b shows that $N$ in glacialage ice decreases with depth. Figure 2 shows that the number of air-hydrate crystals smaller than $100 \mu \mathrm{m}$ in diameter in the glacial-age ice decreases with depth. These results suggest that the larger crystals grow gradually in the ice sheet in compensation for the disappearance of smaller ones.

Figure $4 \mathrm{~b}$ and c shows that $N$ and $V m$ change appreciably in the interglacial period (stage $G$ ), that is to say $N$ in the interglacial age is about half of that at the end of stage $\mathrm{H}$ ice, while $V m$ is nearly three times larger. Such a large $V m$ in stage $\mathrm{G}$ cannot be explained by the general growth of air-hydrate crystals expressed by Equation (2). It can, therefore, be inferred that the large variation in $N$ and $V m$ during the interglacial period may be caused by the original variation in the number concentration and mean volume of air bubbles from which the air-hydrates were generated.

On the other hand, the number concentration of air bubbles in Holocene ice was found to be about three times smaller than that in ice formed during the LGM, while the bubble diameter seemed to be larger in the Holocene than in the LGM ice (Barkov and Lipenkov, 1984). This tendency of large volume with small number concentration of air bubbles in the warm period coincides qualitatively with the inference derived above for the 
Sangamon warm period. Therefore, it is concluded that an abrupt change in the depth profiles of both the number concentration and the mean volume of airhydrate indicates a climatic change.

The crystal growth of air-hydrate requires diffusion of the air molecule in ice. The crystal-growth rate of airhydrate in the deeper regions of an ice sheet may be larger because the temperature of the ice is higher (Ritz, 1989). If so, the variation in $V m$ with climatic change will be concealed by each period of crystal growth below a certain depth.

\section{Comparison of $V$ with total gas content}

In the deeper part of the Vostok ice core, air-hydrate crystals can be considered as the total storage of ancient atmospheric gases, because no air bubbles are observed below $1250 \mathrm{~m}$. A gas-hydrate crystal is composed of water-molecule cages in which gas molecules are included. Taking into account the number ratio of air molecules to the total number of cages, or the site occupancy $(\alpha)$, we obtain the geometrical relation between the value of air-hydrate volume $(V)$ and total gas content $(R)$.

It is assumed here that all gases measured as $R$ have been stored in air-hydrate crystals below the depth of airbubble disappearance. The volume of air-hydrate crystals in a unit weight of ice is obtained by $V / \rho$, where $\rho$ is the density of pure ice. The number of air molecules included in the crystal is then calculated by using the crystallographic data of air-hydrate. Total gas content is obtained by converting the number into the volume under the standard temperature and pressure conditions as follows:

$$
\frac{R N o}{R g}=\frac{n \alpha}{\nu} \frac{V}{\rho}
$$

where $R g=2.24 \times 10^{-2} \mathrm{~m}^{3} \mathrm{~mol}^{-1}$ is the gas volume per mole under standard conditions, $N o=6.02 \times 10^{23} \mathrm{~mol}^{-1}$ is Avogadro's number, $n$ is the number of cages in a unit cell of the air-hydrate crystal and $\nu \mathrm{m}^{3}$ is the volume of a unit cell of the crystal. According to the X-ray analytical results for the air-hydrate crystals in the Dye 3 ice core (Hondoh and others, 1990), its crystallographic structure belongs to the structure II of the hydrate, which gave $\nu=$ $4.91 \times 10^{-27} \mathrm{~m}^{3}$ and $n=24$. Substituting the values of constants and the crystal-structural data, the site occupancy $\alpha$ is given by the following equation

$$
\alpha=5.0 \times 10^{-3} \frac{R}{V} .
$$

Now we can calculate the mean value of $\alpha$ using Equation (4) for all samples below the depth of air-bubble disappearance, i.e. below $1250 \mathrm{~m}$. Total gas content for each sample in the fresh Vostok ice cores measured by Martinerie (1990) and Lipenkov and others (in press) is listed in Table 2. Figure 5 shows the depth variation in $\alpha$ calculated by Equation (4) using the data for $R$ in Table 2 and those for $V$ in Figure $4 a$. It can be seen that the value of $\alpha$ is about unity at a depth just below bubble disappearance. Then $\alpha$ decreases with depth down to about 0.58 , which is the mean value of $\alpha$ for samples at
Table 2. Profiles of each sample. Total gas content was measured by Lipenkov and others (in press)

\begin{tabular}{|c|c|c|c|}
\hline 1050 & B & & Clear, a few small bubbles \\
\hline 1150 & B & & Clear, a few small bubbles \\
\hline 1222 & A & & $\begin{array}{l}\text { Small cracks, small and } \\
\text { large bubbles }\end{array}$ \\
\hline 1251 & B & & Clear \\
\hline 1350 & B & 0.0872 & Clear \\
\hline 1421 & B & 0.0808 & Clear \\
\hline 1430 & B & 0.0821 & Clear \\
\hline 1470 & B & 0.0981 & Clear \\
\hline 1501 & B & 0.0947 & Clear \\
\hline 1514 & A & 0.0923 & $\begin{array}{l}\text { Small cracks, small and } \\
\text { large bubbles }\end{array}$ \\
\hline 1651 & B & 0.0880 & Clear \\
\hline 1796 & A & 0.0898 & Small and large bubbles \\
\hline 1800 & B & 0.0919 & Clear \\
\hline 1811 & B & 0.0909 & Clear \\
\hline 1821 & B & 0.0914 & Clear \\
\hline 1838 & A & 0.0882 & $\begin{array}{l}\text { Large but thin cracks, } \\
\text { small and large bubbles }\end{array}$ \\
\hline 1851 & B & 0.0880 & Clear \\
\hline 1891 & B & 0.0845 & Clear \\
\hline 1910 & B & 0.0848 & Clear \\
\hline 1941 & B & 0.0898 & Clear \\
\hline 1950 & B & 0.0902 & Clear \\
\hline 1980 & B & 0.0944 & Clear \\
\hline 2001 & B & 0.0946 & Clear \\
\hline 2004 & A & 0.0938 & Small and large bubbles \\
\hline 2011 & B & 0.0928 & Clear \\
\hline 2031 & B & 0.0993 & Clear \\
\hline 2041 & B & 0.0937 & Clear \\
\hline 2101 & B & 0.0943 & Clear \\
\hline 2131 & B & 0.0854 & Clear \\
\hline 2151 & B & 0.0849 & Clear \\
\hline 2170 & B & 0.0957 & Clear \\
\hline 2351 & B & 0.0957 & Clear \\
\hline 2452 & B & 0.0999 & Clear \\
\hline 2542 & B & 0.0866 & Clear \\
\hline
\end{tabular}

$\begin{array}{cl}\text { Depth Series } & \begin{array}{l}\text { Total gas } \\ \text { content }\end{array} \\ \mathrm{m} & \mathrm{cm}^{3} \mathrm{~g}^{-1}\end{array}$

stage G. In stage $H, \alpha$ increases with depth up to about 0.85 , while the mean value for all data is approximately 0.79 .

In stage $\mathrm{G}, V$ is larger and $\alpha$ is smaller than those in stage $H$. As described in the previous section, the depth profiles of $N$ and $V m$ of air-hydrate crystals are largely affected by the climate of periods when air bubbles were closed off, in addition to slow growth of the air-hydrates themselves in ice. Likewise, variations in both $V$ and $\alpha$ may also be attributed to the climate. Raynaud and Lebel (1979) revealed that the pore volume at close-off $V c$ is directly proportional to the surface temperature of the 
AGE [kyr]

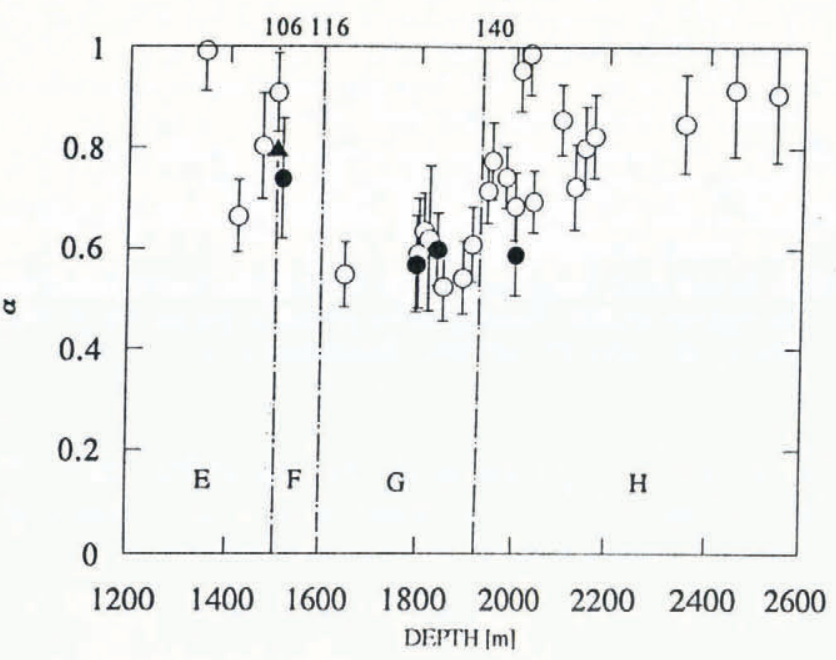

Fig. 5. Number ratio of the air molecules to the total number of cages $(\alpha)$ calculated from the volume concentration of air-hydrate and total gas content measured by Lipenkov and others (in press). Error ranges of the calculation are also shown. The data of the $A$ series are shown by solid symbols and those of the $B$ series by open symbols. The solid triangle shows the cage occupancy of the crystals in the Dye 3 ice obtained from X-ray diffraction analysis (Hondoh and others, 1990).

ice sheet. Therefore, $V c$ in the interglacial age must be larger than that in the glacial age and naturally so does $V$.

The crystalline site occupancy of natural air-hydrate crystals in an ice core of $1500 \mathrm{~m}$ depth obtained at Dye 3, Greenland, was determined at about 0.8 (shown by the solid triangle in Figure 5) by the X-ray diffraction method (Hondoh and others, 1990). Although the $1500 \mathrm{~m}$ ice core of Dye 3 corresponds to the Holocene interglacialage ice (Dansgaard and others, 1985), this value is larger than 0.58, the mean value of $\alpha$ in the Sangamon interglacial ice obtained during the present study. The reason for this difference is not yet clear. The answer will be given when $\alpha$ is determined systematically on the Vostok ice core using the X-ray diffraction method, which is now under way.

\section{CONGLUSIONS}

Air-hydrate crystals included in 34 ice-core samples from Vostok Station, Antarctica, were observed using an optical microscope. The depth range of the samples was between 1050 and $2542 \mathrm{~m}$. The shape and diameter measurements of each air-hydrate crystal were carried out to obtain the depth profiles of the shape, volume concentration, number concentration and mean volume of each crystal. The number ratio of the spherical crystals was more than 0.5 below $1050 \mathrm{~m}$, and that of the faceted crystals was almost constant, at about 0.25 . The volume concentration of air-hydrate in stage G (the interglacial ice) was about $30 \%$ larger than that in stage $\mathrm{H}$ (the glacial-age ice). The number concentration of air-hydrate in the glacial age decreased slightly with depth, and that in the interglacial ice was about half of that in the glacial- age ice. The mean volume of air-hydrate during the glacial age increased gradually with depth and that in the interglacial age was almost three times larger than that in the glacial age. These results indicate that the depth profiles of air-hydrate are influenced by a climatic change. They also indicate that the larger air-hydrate crystals grew slowly in the ice sheet below $1050 \mathrm{~m}$ in compensation for the disappearance of smaller crystals, and the growth rate of the crystals in the glacial-age ice is estimated to be about $6.7 \times 10^{-12} \mathrm{~cm}^{3} \mathrm{year}^{-1}$. The depth profiles of the crystal shape support this conclusion. Two types of ice core, which had undergone different storage conditions, were used for observations to consider the ageing effect during ice-core storage. The depth profiles of air-hydrate in these cores coincided with each other, except those for the crystal shape and the number concentration in ice cores shallower than $1514 \mathrm{~m}$. This indicates that the ageing effect on the ice core during storage is not observed in those from deeper regions. The volume concentration of air-hydrate in each sample was compared with the data for total gas content. The mean value of the proportional constant between them (parameter $\alpha$ in Equation (4)) coincides with the site occupancy of air-hydrate determined experimentally on the $1500 \mathrm{~m}$ ice core obtained at Dye 3, Greenland. However, $\alpha$ varies with depth in the Vostok ice core, about $30 \%$ lower in the Sangamon interglacial ice than that in the glacial-age ice.

\section{AGKNOWLEDGEMENTS}

We are most grateful to all Russian and French participants in drilling, field work and ice sampling. We thank Dr J. Ocampo, Dr D. Raynaud, Dr A. Higashi, Dr H. Shoji and Mr T. Kameda for helpful discussion. This work was supported financially by the Asahi Glass Foundation and the Science and Technology Agency of Japan.

\section{REFERENGES}

Barkov, N. I. and V.Ya. Lipenkov. 1984. Kolichestvennaya kharakteristika struktury l'da do glubiny $1400 \mathrm{~m}$ v rayone stantsii Vostok v Antarktide [Numerical characteristics of ice structure down to a depth of $1400 \mathrm{~m}$ in the region of Vostok station, Antarctica]. Mat. Glyatsiol. Issled. 51, 178-186.

Dansgaard, W., H. B. Clausen, N. Gundestrup, S.J. Johnsen and C. Rygner. 1985. Dating and climatic interpretation of two deep Greenland ice cores. In Langway, C. C., Jr, H. Oeschger and W. Dansgaard, eds. Greenland ice core: geophysics, geochemistry, and the environment. Washington, DC, American Geophysical Union, 71-76. (Geophysical Monograph 33.)

Hondoh, T. 1989. Growth process of clathrate-hydrate crystals in deep ice sheet. Journal of the Japanese Association of Crystal Growth, 16, 149 161. [In Japanese.]

Hondoh, T., H. Anzai, A. Goto, S. Mae, A. Higashi and C. C. Langway, Jr. 1990. The crystallographic structure of the natural air-hydrate in Greenland Dye-3 deep ice core. Fournal of Inclusion Phenomena and Molecular Recognition in Chemistry, 8(1-2), 17-24.

Jouzel, J., J. R. Petit and D. Raynaud. 1990. Palaeoclimatic information from ice cores: the Vostok records. Trans. R. Soc. Edinburgh: Earth Sci., 81, 349-355.

Lipenkov, V.Ya. 1989. Obrazovaniye i razlozheniye gidratov vozdukha $v$ lednikovom l'du [Formation and decomposition of air hydrates in glacier ice]. Mat. Glyatsiol. Issled. 65, 58-64. 
Lipenkov, V.Ya. and A.N. Salamatin. 1989. Relaksatsionnnoye rasshireniye ledyanogo kerna iz burovoy skvazhiny na st. Vostok [Volume relaxation of the core from the bore hole at Vostok station]. Antarktika 28, 59-72.

Lipenkov, V.Ya., N. I. Barkov, P. Duval and P. Pimienta. 1989. Crystalline texture of the $2083 \mathrm{~m}$ ice core at Vostok Station, Antarctica. 7. Glaciol., 35(121), 392-398.

Lipenkov, V. Ya., N. I. Barkov, P. Martinerie and D. Raynaud. In press. Air content of ice deposition at Vostok station. Antarktika.

Lorius, C. and 6 others. 1985. A 150,000-year climatic record from Antarctic ice. Nature, 316(6029), 591-596.

Martinerie, P. 1990. Teneur en gaz des glaces polaires. Variations géographiques actuelles, variations au cours du dernier cycle climatique dans la région de Vostok. (Ph.D. thesis, Université de Grenoble (Joseph Fourier).)

Miller, S. L. 1969. Clathrate hydrates of air in Antarctic ice. Science, 165(3892), $489-490$.
Nakahara, J., Y. Shigesato, A. Higashi, T. Hondoh and C. C. Langway, Jr. 1988. Raman spectra of natural clathrates in deep ice cores. Philos. Mag. B, 57(3), 421-430.

Raynaud, D. and B. Lebel. 1979. Total gas content and surface elevation of polar ice sheets. Nature, 281(5729), 289-291.

Ritz, C. 1989. Interpretation of the temperature profile measured at Vostok, East Antarctica. Ann. Glaciol., 12, 138-144.

Shoji, H. and C. C. Langway, Jr. 1982. Air hydrate inclusions in fresh ice core. Nature, 298(5874), 548-550.

Shoji, H. and C. C. Langway, Jr. 1987. Microscopic observations of the air hydrate-bubble. Transformation process in glacier ice. 7 . Phys. (Paris), 48, Collog. C1, 551-556. (Supplément au 3.)

The accuracy of references in the text and in this list is the responsibility of the authors, to whom queries should be addressed.

MS received 7 October 1991 and in revised form 25 August 1992 